\title{
A 9-Year-Old Girl Presenting Central Precocious Puberty with Polycystic Ovary Syndrome
}

\author{
Kanshi Minamitani ${ }^{1)}$, Hiromichi Nakajima1), Akira Hoshioka ${ }^{1}$, ${ }^{1}$ Kazuto Tamai ${ }^{1)}$, Tomomichi Kurosaki ${ }^{1}$, \\ Reiko Matsumoto'), Masanori Minagawa ${ }^{3)}$ and Yoichi Kohno ${ }^{3)}$ \\ 1)Department of Pediatrics, ${ }^{2}$ Department of Obstetrics and Gynecology, Chiba Municipal Kaihin Hospital, Chiba, \\ 3)Department of Pediatrics, Graduate School of Medicine, Chiba University, Chiba, Japan
}

\begin{abstract}
A 9-year-old girl presented central precocious puberty (CPP) with polycystic ovary syndrome (PCOS) simultaneously. She had obesity, hirsutism and acanthosis nigricans. Laboratory examination revealed high levels of serum LH, FSH ( $\mathrm{LH}>\mathrm{FSH})$, testosterone and insulin. The response of dehydroepiandrosterone sulfate after administration of ACTH was normal for a female. She has been treated with GnRH analog and weight reduction. Excessive androgen production results from ovarian defect and therefore, functional ovarian hyperandrogenism and hyperinsulinemia might be major factor in the pathogenesis. This case is the first report of a PCOS woman demonstrating CPP simultaneously.
\end{abstract}

Key words: central precocious puberty, polycystic ovary syndrome, hyperinsulinemia, hyperandrogenism, GnRH analog

\section{Introduction}

Polycystic ovary syndrome (PCOS) was described by Stein and Leventhal in 1935 (1) and characterized by chronic anovulation and hyperandrogenism. Possible causes are dysregulation of LH secretion by the hypothalamus or abnormalities of ovaries or adrenal glands or hyperinsulinemia, but its etiology remains unknown (2-4).

We report the first case of a PCOS patient demonstrating central precocious puberty (CPP) simultaneously. Some reports show patients with CPP followed by PCOS and suggest some

Received: May 2, 2002

Accepted: June 14, 2002

Correspondence: Dr. Kanshi Minamitani, Department of Pediatrics, Chiba Municipal Kaihin Hospital, 3-31-1 Isobe, Mihama-ku, Chiba 261-0012, Japan. relationships between these diseases, which involve abnormal regulation of gonadotropin secretion (5-10). The mechanism in a PCOS girl presenting CPP remains unknown.

\section{Case Report}

A 9-year 7 month-old girl was referred because of vaginal bleeding. She was born uneventfully after a full-term gestation. Birth weight was $3422 \mathrm{~g}$ and length was $49.5 \mathrm{~cm}$. She showed signs of obesity from the age of 4 (23.3\% above the ideal weight for height). She was first noted to have bilateral breast development at the age of 7 , followed by pubic hair growth at the age of 8 . Her height velocity was increased and obesity and hirsutism had progressed since seven years of age.

On the first visit to our hospital, her height and weight were $147.7 \mathrm{~cm}$ (2.35 SD) and $66.3 \mathrm{~kg}$ (body 
Table 1 Laboratory findings at diagnosis

\begin{tabular}{lclc}
\hline GH & $0.8 \mathrm{ng} / \mathrm{ml}$ & UA & $6.8 \mathrm{mg} / \mathrm{dl}$ \\
IGF-I & $837 \mathrm{ng} / \mathrm{ml}$ & GOT & $19 \mathrm{U} / \mathrm{l}$ \\
TSH & $1.45 \mu \mathrm{IU} / \mathrm{ml}$ & GPT & $11 \mathrm{U} / \mathrm{l}$ \\
$\mathrm{T}_{3}$ & $206 \mathrm{ng} / \mathrm{dl}$ & ALP & $1089 \mathrm{U} / \mathrm{l}$ \\
$\mathrm{T}_{4}$ & $8.6 \mu \mathrm{g} / \mathrm{dl}$ & T-cho & $152 \mathrm{mg} / \mathrm{dl}$ \\
$\mathrm{LH}$ & $6.1 \mathrm{mIU} / \mathrm{ml}$ & TG & $159 \mathrm{mg} / \mathrm{dl}$ \\
$\mathrm{FSH}$ & $3.6 \mathrm{mIU} / \mathrm{ml}$ & glucose & $88 \mathrm{mg} / \mathrm{dl}$ \\
$\mathrm{HCG}$ & $<1.0 \mathrm{mIU} / \mathrm{ml}$ & insulin & $19 \mu \mathrm{U} / \mathrm{ml}$ \\
$\mathrm{PRL}$ & $17.2 \mathrm{ng} / \mathrm{ml}$ & (insulin/glucose=0.22) \\
$\mathrm{E}_{1}$ & $49.0 \mathrm{pg} / \mathrm{ml}$ & CPR & $3.4 \mathrm{ng} / \mathrm{ml}$ \\
$\mathrm{E}_{2}$ & $98 \mathrm{pg} / \mathrm{ml}$ & HbAic & $4.8 \%$ \\
testosterone & $100 \mathrm{ng} / \mathrm{dl}$ & urinary & \\
DHEAS & $1210 \mathrm{ng} / \mathrm{ml}$ & glucose & $(-)$ \\
17-OHP & $3.6 \mathrm{ng} / \mathrm{ml}$ & ketone body & $(-)$ \\
\hline
\end{tabular}

Table 2 Endocrinological data at diagnosis

\begin{tabular}{lllccccc}
\hline & & & 0 min & 30 min & 60 min & 90 min & 120 min \\
\hline LH-RH test & LH & $(\mathrm{mIU} / \mathrm{ml})$ & 6.1 & 52.8 & 63.2 & 75.6 & 95.7 \\
& FSH & $(\mathrm{mIU} / \mathrm{ml})$ & 3.6 & 10.3 & 13.3 & 17.6 & 21.7 \\
TRH test & $\mathrm{E} 2$ & $(\mathrm{pg} / \mathrm{ml})$ & 98 & & & & 129 \\
& $\mathrm{TSH}$ & $(\mu \mathrm{IU} / \mathrm{ml})$ & 1.45 & 8.64 & 6.27 & 4.39 & 3.65 \\
Arginine tolerance test & $\mathrm{PRL}$ & $(\mathrm{ng} / \mathrm{ml})$ & 17.2 & 23.5 & 15.4 & 12.8 & 14.7 \\
Insulin tolerance test & $\mathrm{GH}$ & $(\mathrm{ng} / \mathrm{ml})$ & 27.4 & 28.6 & 39.9 & 30.6 & 18.0 \\
& cortisol & $(\mu \mathrm{m} / \mathrm{dl})$ & 4.1 & 1.3 & 6.3 & 15.3 & 27.4 \\
& & & 10.8 & 17.6 & 14.0 & 18.2 & 24.9 \\
\hline
\end{tabular}

mass index: 30.4), respectively. The breast and pubic hair were at Tanner stage $\mathrm{IV}$ and lll, respectively. She had hirsutism and acanthosis nigricans. Her bone age assessed by the GreulichPyle method was 12 yrs old.

Laboratory examination revealed high levels of serum LH, FSH ( LH > FSH) and testosterone (Table 1). The basal and maximal concentrations of LH after administration of LH-releasing hormone (LHRH) were high, although the levels of FSH remained in the normal range (Table 2). The basal concentration of TSH was normal and the peak level after TRH administration was also normal (Table 2). Although the basal concentration of PRL was slightly increased, the peak level after TRH administration was normal
(Table 2). The ratio of serum insulin to plasma glucose was slightly elevated $(19 / 88=0.22)$ (Table 1). Ultrasonography and magnetic resonance imaging (MRI) of the abdomen revealed bilateral polycystic ovaries (Fig. 1A, B). MRI of the pituitary gland showed no central nervous system abnormalities including hypothalamic-pituitary tumors (Fig. 2A, B). After eight months' treatment with GnRH analog, the basal levels and maximal responsiveness of dehydroepiandrosterone sulfate (DHEAS), androstenedione, testosterone and $17 \alpha-$ hydroxyprogesterone (17-OHP) in response to administration of ACTH were normal for pubertal females (Table 4). On the basis of these investigations, PCOS with CPP was diagnosed.

She has been treated with GnRH analog and 
A

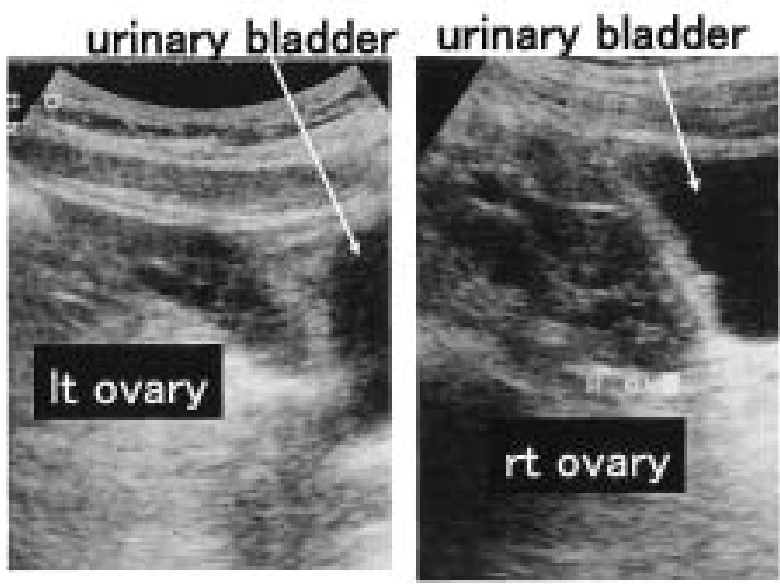

B

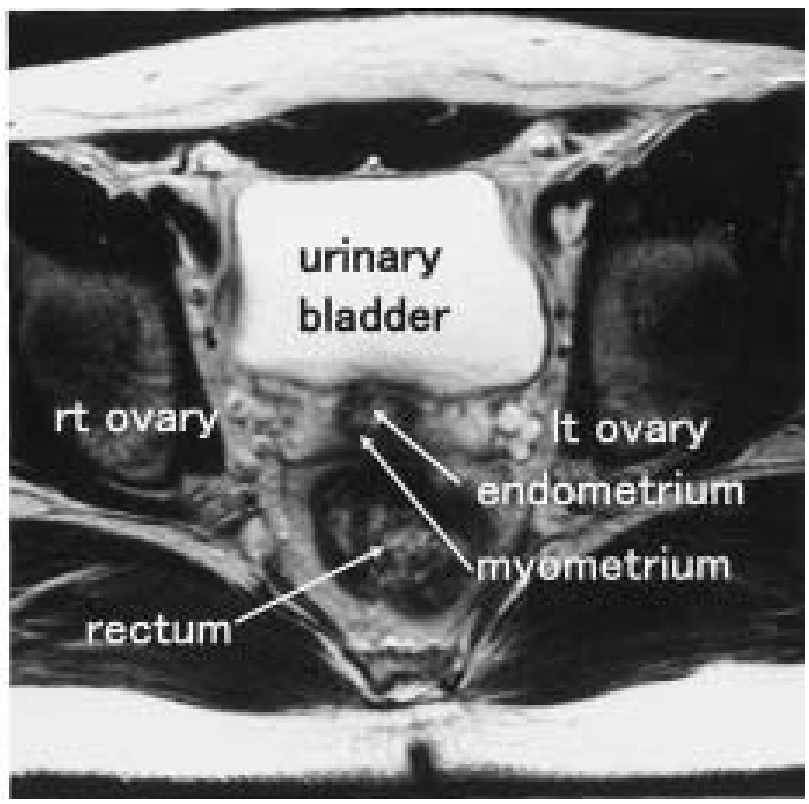

Fig. 1 Unenhanced sonogram (A) and axial unenhanced T2-weighted MR image (B) of ovary at diagnosis.

A

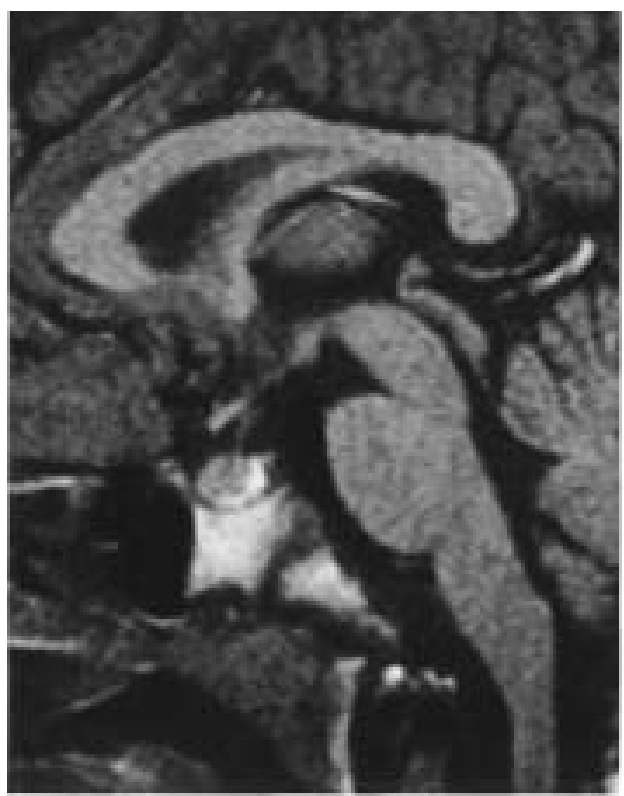

B

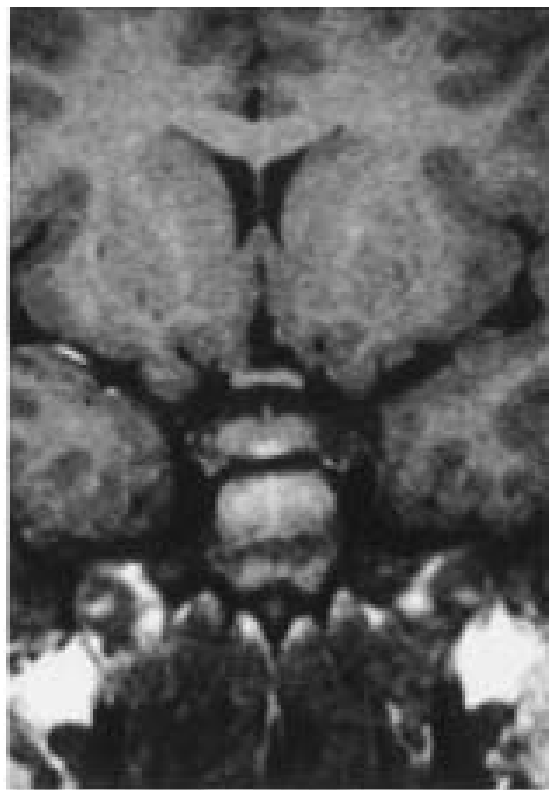

Fig. 2 Sagittal (A) and coronal (B) unenhanced T1-weighted MR image of pituitary gland at diagnosis. 
Table 3 Serum hormone concentrations after 4 months of GnRH analog treatment

\begin{tabular}{lccccc}
\hline $\begin{array}{l}\text { IGF-I } 707 \mathrm{ng} / \mathrm{ml}, \\
\text { Fasting plasma glucose, } \\
\text { Postprandial plasma glucose, }\end{array}$ & $\begin{array}{l}\text { DHEAS } 1170 \mathrm{ng} / \mathrm{ml} / \mathrm{dl} \text {, insulin } 13 \mu \mathrm{U} / \mathrm{ml} \\
94 / \mathrm{dl} \text {, insulin } 30 \mu \mathrm{U} / \mathrm{ml}\end{array}$ \\
\hline LH-RH test & before & $30 \mathrm{~min}$ & $60 \mathrm{~min}$ & $90 \mathrm{~min}$ & $120 \mathrm{~min}$ \\
\hline & 0.6 & 1.7 & 1.2 & 0.9 & 0.8 \\
& 3.3 & 4.9 & 4.3 & 4.2 & 4.1 \\
$\mathrm{LH}(\mathrm{mIU} / \mathrm{ml})$ & $<10$ & & & & $<10$ \\
FSH (mIU/ml) & 30 & & & & 30 \\
E $_{2}(\mathrm{pg} / \mathrm{ml})$ & & & & & \\
testosterone (ng/dl) & &
\end{tabular}

Table 4 Responses to rapid ACTH test after 8 months of GnRH analog treatment

\begin{tabular}{lcccc}
\hline & & 0 min & 30 min & 60 min \\
\hline cortisol & $(\mu \mathrm{g} / \mathrm{dl})$ & 23.8 & 25.7 & 31.8 \\
progesterone & $(\mathrm{ng} / \mathrm{ml})$ & 1.1 & 1.5 & 1.5 \\
17-OHP & $(\mathrm{ng} / \mathrm{ml})$ & 3.0 & 3.7 & 3.6 \\
androstenedione $(\mathrm{ng} / \mathrm{ml})$ & 2.3 & 2.4 & 2.3 \\
DHEAS & $(\mathrm{ng} / \mathrm{ml})$ & 2120 & 1850 & 1690 \\
testosterone & $(\mathrm{ng} / \mathrm{dl})$ & 20 & 30 & 20 \\
\hline
\end{tabular}

weight reduction induced by a standardized hypocaloric diet consisting of 1500 kcal daily based on the food exchange list of the Japan Diabetes Society and an exercise program. Treatment with GnRH analog resulted in prompt cessation of breast development and vaginal bleeding and arrested progression of hirsutism along with a deceleration of growth velocity and bone maturation. Adequate suppression was biologically documented by reductions in the concentrations of basal $\mathrm{LH}$, estradiol, PRL, and testosterone and prepubertal response to LHRH testing (Fig. 3, Table 3). Likewise, the ratios of LH to FSH at baseline were normalized after treatment. The DHEAS levels were within the normal range and did not change after GnRH analog treatment. Basal serum insulin levels were decreased after dietary weight reduction. As noted in Fig. 4, the MR image after 4 months of GnRH analog treatment showed regression of polycystic ovaries.

\section{Discussion}

The endocrinological features of PCOS are hyperandrogenism, increased concentration of $\mathrm{LH}$ or an increase in the ratio of LH to $\mathrm{FSH}$, and increased levels of estrone and insulin. The pathogenesis of PCOS has been variously ascribed to primary abnormalities of LH regulation, ovaries, adrenal glands or recently hyperinsulinemia. But the etiology of this disorder including the source of androgen remains elusive.

If a girl develops secondary sexual characteristics before the age of seven years, she is considered to have sexual precocity. Our patient was diagnosed as CPP on the basis of the early onset of thelarche, pubarche, menarche, increased height velocity and advanced bone maturation. 


\begin{tabular}{|c|c|c|c|c|c|c|c|}
\hline & & & & & & & \\
\hline & before & 1month & 2months & 3months & 4 months & 5months & 8months \\
\hline basal LH & 6.1 & 9.1 & 2.8 & 0.8 & 0.6 & 0.5 & 0.4 \\
\hline basal FSH & 3.6 & 6.4 & 3.9 & 3.0 & 3.3 & 1.8 & 2.8 \\
\hline $\mathrm{E}_{2}$ & 98 & $<10$ & $<10$ & $<10$ & $<10$ & $<10$ & $<10$ \\
\hline PRL & 17.2 & & 7.6 & 7.0 & & 6.4 & 12.7 \\
\hline testosterone & 100 & 60 & 50 & 40 & 30 & 30 & 20 \\
\hline DHEAS & 1210 & 980 & 1330 & 1070 & 1170 & & 1230 \\
\hline IGF-I & 837 & 878 & 817 & 681 & 707 & 684 & 741 \\
\hline ALP & 1089 & 1039 & 1021 & 854 & 764 & 715 & 759 \\
\hline fasting insulin & 19 & 128 & 25 & 153 & 30 & 8 & 18 \\
\hline fasting glucose & 100 & 95 & 84 & & 94 & 80 & 86 \\
\hline BW & 66.3 & 67.0 & 66.0 & 67.7 & 62.5 & 60.9 & 66.0 \\
\hline
\end{tabular}

Fig. 3 Clinical course.

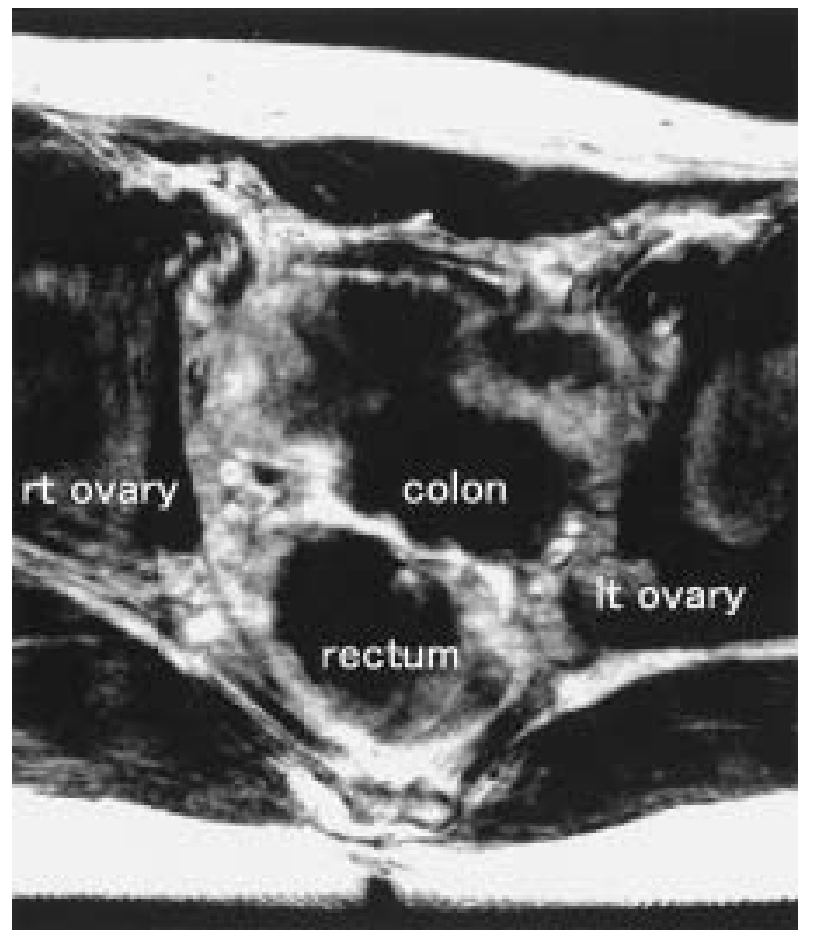

Fig. 4 Axial unenhanced T2-weighted MR image of ovary three months after GnRH analog treatment.
Obesity, hirsutism and enlarged polycystic ovaries associated with high concentrations of $\mathrm{LH}$, androgen and insulin were consistent with PCOS. On the other hand, late onset congenital adrenal hyperplasia (nonclassical $\mathrm{CAH}$ ) also causes adrenal hyperandrogenism and precocious puberty. Our patient had typical clinical features of PCOS-obesity, hirsutism, enlarged polycystic ovaries, hypersecretion of LH and insulin. The rapid ACTH stimulation produced normal responses of serum 17-OHP, DHEAS, androstenedione and testosterone after gonadal suppression therapy. Therefore her adrenal gland function might be normal, and nonclassical $\mathrm{CAH}$ was excluded.

Petrus et al. (5), Root et al. (6), Ibanez et al. (7), Pienkowski et al. (8), Lazar et al. (9) and Kumazaki et al. (10) independently reported cases of patients who presented with precocious puberty and later developed PCOS, and there are some relationships between these diseases, having the abnormal regulation of gonadotropin secretion. This case is the first report of a PCOS woman demonstrating CPP.

Progesterone, 17-OHP and testosterone 


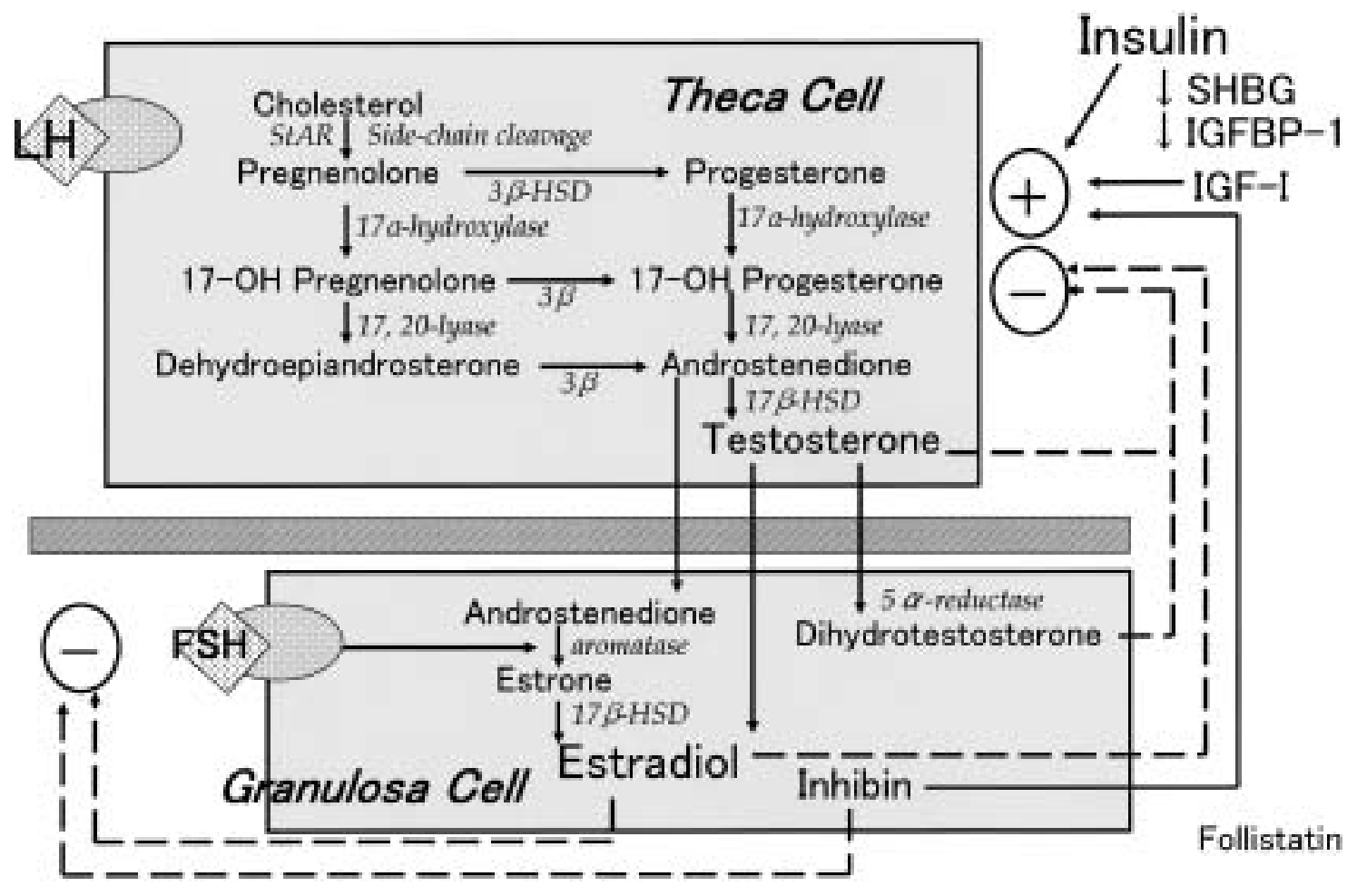

Fig. 5 Mechanism of ovarian steroidogenesis.

production per cell were more noticeably increased in propagated theca cell cultures from PCOS than in controls $(11,12) .17 \alpha$-hydroxylase/ 17,20-desmolase (CYP17), 3 $\beta$-hydroxysteroid dehydrogenase ( $3 \beta$-HSD), steroidogenic acute regulatory protein (StAR) and cholesterol side chain cleavage enzyme (CYP11A) activities per theca cell are augmented in PCOS theca cells compared with normal cells, and therefore it is proposed that excess androgen production in PCOS results from dysregulation of CYP 17 enzyme, the key enzyme required for androgen production in theca cells, activity due to an intrinsic ovarian defect. LH first stimulates P450c17 gene expression. As LH stimulation continues, reduction of $\mathrm{P} 450 \mathrm{c} 17$ messenger ribonucleic acid (mRNA) and enzyme content ensues in theca cells. The total $5 \alpha$-reductase activity was approximately 4-fold higher in PCOS follicles than in control follicles and the high concentrations of 5 -reduced androgens, $5 \alpha$ - androstane-3,17-dione produced from androstenedione, in polycystic ovaries are capable of greatly inhibiting human granulosa cell aromatase activities by functioning as a competitive inhibitor and suppress estradiol production by $75 \%(13,14)$. Yong et al. reported that treatment with FSH, but not LH, increased aromatase activity in immature granulosa cells (15).

Recent data also suggest in that steroidogenic enzyme mRNA may be overexpressed in PCOS theca cells, and the mean levels of LH receptor mRNA expression were higher in theca cells and granulosa cells from polycystic ovaries than in control follicles (16). Granulosa cells from women with polycystic ovaries prematurely respond to $\mathrm{LH}$ (17). If LH levels are raised above a certain threshold level, premature luteinization may be started. The theca cells are hyperstimulated and granulosa cells may be prematurely luteinized. Premature exposure of granulosa cells to LH 
inhibits their proliferation. A balance between FSH and $\mathrm{LH}$ is required for follicle development and ovulation, such that development of the dominant follicle is arrested. This may be important in the mechanism of anovulation in PCOS.

Although our patient has a high concentration of LH and imbalance between FSH and LH, she has shown signs of premature menarche and the mechanism remains unknown. In this case, gonadal suppression therapy resulted in reduction in the concentrations of LH, FSH, estradiol and testosterone; otherwise the DHEAS level was within the normal range: decrease in the high level of LH followed the decrease in the testosterone concentration. The rapid ACTH stimulation produced normal responses of serum 17-OHP, DHEAS, androstenedione and testosterone after gonadal suppression therapy. It is speculated that the hyperandrogenism in this case might be caused by hypothalamic-pituitary dysfunction of gonadotropin secretion and ovarian androgens, but not by the adrenal gland.

The ovarian androgen excess is usually accompanied by hyperinsulinemia and dyslipidemia in PCOS $(2,3)$. PCOS is associated with an increased risk of developing impaired glucose tolerance and type 2 diabetes mellitus resulting from profound reductions in insulin sensitivity and insulin secretary dysfunction, and inheritability of $\beta$-cell dysfunction is likely to be a significant factor in the predisposition to diabetes (18). Adashi et al. (19) reported that in vitro treatment of primary culture cells from rat anterior pituitary incubated for two days in the presence of insulin resulted in significant increases in both the basal and the maximal release of LH and FSH. Therefore, gonadotroph constituted a target cell of insulin, and insulin might act directly on the anterior pituitary in the regulation of gonadotropin release. An increased insulin level in PCOS may be a major factor causing premature maturation of granulosa cells and increase the ability of granulosa cells to respond to LH. Hyperinsulinemia may play a pathogenetic part in hyperandrogenism in women with PCOS by increasing ovarian CYP17 enzyme activity and decreasing the serum sex hormone binding globulin (SHBG) concentration (3). Nestler et al. reported that insulin and IGF-I stimulated human thecal testosterone biosynthesis with inositolglycans as the signal transduction system in the PCOS (20). Dietary weight reduction and exercise have been shown to decrease ovarian P450c17 $\alpha$ activity and serum free testosterone concentrations and improve insulin sensitivity, LH levels, menstrual disturbance and infertility in obese women with PCOS (21-23). Insulinsensitizing treatment, with such as metformin and troglitazone, has been reported to ameliorate hyperinsulinemia, hirsutism, hyperandrogenism, and to restore ovulation in women, reducing ovarian cytochrome P450c17 $\alpha$ activity (24-26). Although our patient still showed signs of obesity and hyperinsulinemia before weight reduction therapy, her testosterone concentration was decreased with gonadal suppression therapy. Dietary weight reduction and exercise might contribute to improvement of hyperinsulinemia. Therefore, the role of obesity and hyperinsulinemia in development of the gonadotropin-ovary system and hyper-androgenism might be small in this case.

Frankly masculinizing plasma concentrations of androgens are capable of inducing the histological changes in PCOS in the ovary and bringing about follicle maturation arrest (4). In virilizing classic $\mathrm{CAH}$, polycystic ovaries may be caused by the same mechanism. Excessive production of adrenal androgens can supply substrate for extragonadal aromatization and result in tonic estrogen inhibition of FSH secretion. Although CPP may occur when the prepubertal child has previously been exposed to excessive levels of endogenous or exogenous androgens, most patients with premature adrenarche enter puberty and experience menarche within the normal age range. On the other hand, hyperinsulinemia can stimulate adrenal and 
ovarian steroidogenesis. Insulin resistance accompanies puberty and may contribute to adrenarche (3). In our case, the DHEAS level was within the normal range in the clinical course and the rapid ACTH stimulation produced normal responses of serum DHEAS, androstenedione and testosterone after gonadal suppression therapy. Therefore her hyperandrogenism might not result from excessive production of adrenal androgens.

The mechanism of a PCOS girl presenting CPP remains unknown. Hyperinsulinemia, increased early insulin responses to glucose, increased glucose uptake rate in peripheral tissues, high free androgen indexes, and decreased SHBG and IGF binding protein-1 levels are present in most girls with CPP, which is closely related to the characteristics of PCOS (27).

Some pathways including steroid hormone synthesis, gonadotropin action and the insulin signaling mechanism have been implicated in the etiology of PCOS. To understand the complex genetics of PCOS, several genes from these pathways have been tested as candidate genes. CYP11a, encoding P450 cholesterol side chain cleavage, the insulin gene (INS) variable number tandem repeat (VNTR), and follistatin gene appear to be potential disease loci for PCOS (28). Although abnormalities in the regulation of $17-\alpha$ hydroxylase/17,20 lyase in PCOS have been reported, linkage analysis excluded CYP17 as a major susceptibility gene for PCOS. The INS-VNTR has been shown to be involved in the regulation of insulin gene expression and implicated in the etiology of type 2 diabetes. Follistatin, an activinbinding protein, neutralizes the biological activity of activin and may function as a reservoir for activins (29). Activin promotes ovarian follicular development, inhibits theca cell androgen production, and increases pituitary FSH secretion. Overexpression of follistatin in transgenic mice results in the suppression of serum levels of FSH and arrested ovarian folliculogenesis (30). These are all characteristic features of PCOS.

In conclusion, in this patient with PCOS presenting $\mathrm{CPP}$, which is the first report, excess androgen production results from an ovarian defect. Functional ovarian hyperandrogenism and hyperinsulinemia might play a major pathogenetic part, but details of the mechanism remain unknown.

\section{References}

1. Stein IF, Leventhal ML. Amenorrhea associated with bilateral polycystic ovaries. Am J Obstet Gynecol 1935;29:181-91.

2. Dunaif A. Insulin resistance and the polycystic ovary syndrome: Mechanism and implication for pathogenesis. Endocr Rev 1997;18:774-800.

3. Poretsky L, Cataldo NA, Rosenwaks Z, Giudice LC. The insulin-related ovarian regulatory system in health and disease. Endocr Rev 1999;20:535-82.

4. Ehrmann DA, Barnes RB, Rosenfield RL. Polycystic ovary syndrome as a form of functional ovarian hyperandrogenism due to dysregulation of androgen secretion. Endocr Rev 1995;16:322-53.

5. Petrus M, Dutau G, Rochiccioli P. The succession of precocious puberty and Stein-Leventhal syndrome. Helv Paediatr Acta 1982;37:171-6.

6. Root AW, Moshang T Jr. Evolution of the hyperandrogenism-polycystic ovary syndrome from isosexual precocious puberty: report of two cases. Am J Obstet Gynecol 1984;149:763-7.

7. Ibanez L, Potau N, Virdis R, Zampolli M, Terzi C, Gussinye M, et al. Postpubertal outcome in girls diagnosed of premature pubarche during childhood: increased frequency of functional ovarian hyperandrogenism. J Clin Endocrinol Metab 1993;76:1599-603.

8. Pienkowski C, Tauber MT, Pigeon P, Oliver I, Rochiccioli P. Precocious puberty and polycystic ovarian syndrome: apropos of 13 cases. Arch Pediatr 1995;2:729-34.

9. Lazar L, Kauli R, Bruchis C, Nordenberg J, Galatzer A, Pertzelan A. Early polycystic ovary-like syndrome in girls with central precocious puberty and exaggerated adrenal response. Eur J Endocrinol 1995;133:403-6.

10. Kumazaki K, Kamoda T, Ohto T, Aoki T, Shimakura Y, Mesaki N, et al. Isosexual precocious puberty and polycystic ovary syndrome. Clin 
Pediatr Endocrinol 1996;5:31-6.

11. Nelson VL, Legro RS, Strauss III JF, McAllister JM. Augmented androgen production is a stable steroidogenic phenotype of propagated theca cells from polycystic ovaries. Mol Endocrinol 1999;13:946-57.

12. Nelson VL, Qin KN, Rosenfield RL, Wood JR, Penning TM, Legro RS, et al. The biochemical basis for increased testosterone production in theca cells propagated from patients with polycystic ovary syndrome. J Clin Endocrinol Metab 2001;86:5925-33.

13. Jakimiuk AJ, Weitsman SR, Magoffin DA. 5 $\alpha-$ Reductase activity in women with polycystic ovary syndrome. J Clin Endocrinol Metab 1999;84:24148.

14. Agarwal SK, Judd HL, Magoffin DA. A mechanism for the suppression of estrogen production in polycystic ovary syndrome. J Clin Endocrinol Metab 1996;81:3686-91.

15. Yong EL, Baird DT, Yates R, Reichert Jr LE, Hillier SG. Hormonal regulation of the growth and steroidogenic function of human granulosa cells. $J$ Clin Endocrinol Metab 1992;74:842-9.

16. Jakimiuk AJ, Weitsman SR, Navab A, Magoffin DA. Luteinizing hormone receptor, steroidogenesis acute regulatory protein, and steroidogenic enzyme messenger ribonucleic acids are overexpressed in thecal and granulosa cells from polycystic ovaries. J Clin Endocrinol Metab 2001;86:1318-23.

17. Willis DS, Watson H, Mason HD, Galea R, Brincat M, Franks S. Premature response to luteinizing hormone of granulosa cells from anovulatory women with polycystic ovary syndrome: relevance to mechanism of anovulation. J Clin Endocrinol Metab 1998;83:3984-91.

18. Colilla S, Cox NJ, Ehrmann DA. Heritability of insulin secretion and insulin action in women with polycystic ovary syndrome and their first degree relatives. J Clin Endocrinol Metab 2001;86:2027-31.

19. Adashi EY, Hsueh AJ, Yen SS. Insulin enhancement of luteinizing hormone and folliclestimulating hormone release by cultured pituitary cells. Endocrinology 1981;108:1441-9.

20. Nestler JE, Jakubowicz DJ, de Vargas AF, Brik C,
Quintero N, Medina F. Insulin stimulates testosterone biosynthesis by human thecal cells from women with polycystic ovary syndrome by activating its own receptor and using inositolglycan mediators as the signal transduction system. J Clin Endocrinol Metab 1998;83:2001-5.

21. Nestler JE, Jakubowicz DJ. Decreases in ovarian cytochrome P $450 c 17 \alpha$ activity and serum free testosterone after reduction of insulin secretion in polycystic ovary syndrome. N Engl J Med 1996;335:617-23.

22. Jakubowicz DJ, Nestler JE. 17 $\alpha$-Hydroxyprogesterone responses to leuprolide and serum androgens in obese women with and without polycystic ovary syndrome after dietary weight loss. J Clin Endocrinol Metab 1997;82:556-60.

23. Huber-Buchholz MM, Carey DGP, Norman RJ. Restoration of reproductive potential by lifestyle modification in obese polycystic ovary syndrome: role of insulin sensitivity and luteinizing hormone. J Clin Endocrinol Metab 1999;84:1470-4.

24. Azziz R, Ehrmann DA, Legro RS, Whitcomb RW, Hanley R, Fereshetian AG, et al. Troglitazone improves ovulation and hirsutism in the polycystic ovary syndrome: Multicenter, double blind, placebo-controlled trial. J Clin Endocrinol Metab 2001;86:1626-32.

25. Ehrmann DA, Schneider DJ, Sobel BE, Cavaghan MK, Imperial J, Rosenfield RL, et al. Troglitazone improves defects in insulin action, insulin secretion, ovarian steroidogenesis, and fibrinolysis in women with polycystic ovary syndrome. J Clin Endocrinol Metab 1997;82:210816.

26. Ibanez L, Valls C, Potau N, Marcos MV, de Zegher F. Sensitization to insulin in adolescent girls to normalize hirsutism, hyperandrogenism, oligomenorrhea, dyslipidemia, and hyperinsulinism after precocious pubarche. J Clin Endocrinol Metab 2000;85:3526-30.

27. Ibanez L, Potau N, Zampolli M, Rique S, Saenger P, Carrascosa A. A. Hyperinsulinemia and decreased insulin-like growth factor-binding protein-1 are common features in prepubertal and pubertal girls with a history of premature pubarche. J Clin Endocrinol Metab 1997;82:2283-8. 
28. Franks S, Gharani N, McCarthy M. Candidate gene in polycystic ovary syndrome. Hum Reprod Up 2001;7:405-10.

29. Urbanek M, Legro RS, Driscoll DA, Azziz R, Ehrmann DA, Norman RJ, et al. Thirty-seven candidate genes for polycystic ovary syndrome:
Strongest evidence for linkage is with follistatin. Proc Natl Acad Sci USA 1999;96:8573-8.

30. Guo Q, Kumar TR, Woodruff T, Hadsell LA, DeMayo FJ, Matzuk MM. Overexpression of mouse follistatin causes reproductive defects in transgenic mice. Mol Endocrinol 1998;12:96-106. 